\title{
Pemanfaatan Barang Bekas Sebagai Media Pembalajaran RAPATJURANG (Cara Cepat Penjumlahan dan Pengurangan)
}

\author{
Utilization of Used Goods as Learning Media RAPATJURANG (Quick Way of Addition \\ and Subtraction)
}

\author{
Humairah $^{1}$, Rizka Rismawanda ${ }^{2}$, Zahrotul Khamidah A ${ }^{3}$, Muhammad Shulhudin \\ Mubarok $^{4}$, Ahmad Syifauddin Saud ${ }^{5}$ \\ 1,2,3,4,5 Program Studi Pendidikan Guru Sekolah Dasar, Fakultas Sains Teknologi dan Pendidikan \\ e-mail: irahumairah489@gmail.com
}

\begin{abstract}
Abstrak
Kegiatan pengabdian kepada masyarakat ini bertujuan memberikan sosialisasi dan pelatihan kepada guru dan siswa tentang pembuatan media pembelajaran dengan memanfaatkan barang bekas atau barang barang yang sudah tidak terpakai disekitar lingkungan. Sehingga barangbarang yang sudah tidak terpakai seperti kalender bekas dapat digunakan untuk membuat media pembelajaran yang dapat membantu siswa maupun guru dan siswa untuk kegiatan belajar mengajar. Metode yang digunakan pelaksaan kegiatan pengabdian kepada masyarakat ini dengan ceramah, demonstrasi dan praktik. Produk dari kegiatan pelatihan pembuatan media ini dapat digunakan dalam kegiatan belajar mengajar, sehingga kegiatan belajar lebih menyenangkan dan memotivasi siswa sehingga mudah menerima dan memahami pelajaran. Kegiatan pengabdian kepada masyarakat ini dilaksanakan di SDN Unggulan 4 Made dengan partisipan/sasaran guru kelas II dan siswa-siswanya. Kegiatan ini dilaksanakan bulan Maret 2020. Pelaksanaan ini diawali dengan sosialisasi kepada guru dan kepala sekolah pada tanggal 8 Maret 2020 kemudian dilanjutkan kegiatan pelatihan pada tanggal 9 Maret 2020. Hasilnya siswa bersama dengan guru dapat membuat produk media pembelajaran RAPATJURANG (Cara Penjumlahan dan Pengurangan). RAPATJURANG adalah media pembelajaran yang dapat membatu belajar siswa kelas II dalam menghitung penjumlahan dan pengurangan dengan cara yang mudah.
\end{abstract}

Kata kunci: Matematika, barang bekas, media pembelajaran.

\begin{abstract}
This community service activity aims to provide socialization and training to teachers and students about making learning media by utilizing used goods or items that are not used around the environment. So that unused items such as used calendars can be used to make learning media that can help students as well as teachers and students for teaching and learning activities. The method used in implementing this community service activity is through lectures, demonstrations and practice. The product of this media creation training activity can be used in teaching and learning activities, so that learning activities are more fun and motivate students so that they are easy to accept and understand lessons. This community service activity was carried out at SDN Unggulan 4 Made with the participants/targets of class II teachers and their students. This activity was carried out in March 2020. This implementation began with outreach to teachers and school principals on March 8,2020, then continued with training activities on March 9, 2020. As a result, students and teachers were able to make RAPATJURANG learning media products (How to Add and Subtract). RAPATJURANG is a learning media that can help class II students learn to calculate addition and subtraction in an easy way.
\end{abstract}

Keywords: Mathematics, secondhand, instructional media.

\section{PENDAHULUAN}

Permasalahan pembelajaran dalam lingkungan sekolah di Indonesia akhir-akhir ini terjadi semakin kompleks. Salah satu masalah yang terjadi di SDN Unggulan 4 Made 
pengetahuan tentang pemanfaatan barang bekas pada anak sekolah dasar sudah cukup baik akan tetapi pemanfaatannya sebagai media pembelajaran khusus sabagai media berhitung dalam pembelajaran matematika masih minim. Oleh karena itu, perlu adanya solusi yang berkaitan dengan strategi, metode maupun media pembelajaran yang perlu dipergunakan oleh guru. Berkaitan dengan hal tersebut, guru diharapkan lebih kreatif dan inovatif dalam proses kegiatan belajar mengajar di sekolah lebih bervariasi. Di sini kami bertim melaksanakan pengabdian kepada masyarakat mencoba memberikan pelatihan kepada guru maupun siswa untuk membuat dan mempraktikan media pembelajaran untuk materi pelajaran matematika SD kelas II dengan membuat suatu media pembelajaran RAPATJURANG (Cara Cepat Penjumlahan dan Pengurangan).

SDN Unggulan 4 Made yang terletak di desa Made, Kecamatan Made Kabupaten Lamongan merupakan salah satu sekolah unggulan dengan konsep sekolah Adiwiyata. Dimana konsep sekolah Adiwiyata tersebut mengusung program pendidikan lingkungan hidup, yaitu upaya untuk mendapatkan ilmu pengetahuan dan berbagai norma serta etika yang dapat menjadi dasar manusia menuju terciptanya kesejahteraan hidup untuk cita-cita pembangunan yang berkelanjutan.

Guru di SDN Unggulan 4 Made adalah sekolah dasar negeri yang telah berusaha membuat media pembelajaran untuk merangsang semangat belajar siswa, akan tetapi perlu adanya pelatihan lebih lanjut terkait pembuatan media pembelajaran yang kreatif dan inovatif yang dapat melatih kreativitas guru dalam memanfaatkan barang-barang yang sudah tidak terpakai untuk dibuat menjadi media pembelajaran yang inovatif. Selain itu, media pembelajaran ini nantinya dapat di kembangkan lebih lanjut sesuai kreativitas dan kebutuhan mengajar. Selanjutnya media ini dapat menunjang pembelajaran dan merangsang motivasi dan semangat belajar bagi para siswanya.

Salah satu aspek dalam pembelajaran adalah media pembelajaran, proses pembelajaran merupakan proses komunikasi dan berlangsung dalam suatu sistem, maka media pembelajaran menempati posisi yang cukup penting sebagai salah satu komponen sistem pembelajaran (Duda et al., 2018). Tanpa media, komunikasi tidak akan terjadi dan proses pembelajaran sebagai proses komunikasi juga tidak akan bisa berlangsung secara optimal (Nisa et al., 2019). Media pembelajaran adalah komponen integral dari sistem pembelajaran. Media berperan sebagai pembawa pesan dari sumber kepada penerima, dalam proses pembelajaran, penerima pesan adalah siswa (Humairah, 2018). Pesan yang disalurkan oleh media dari sumber ke penerima yaitu isi pelajaran yang berasal dari kurikulum yang disampaikan oleh guru kepada siswa. Penggunaan media dalam proses pembelajaran dapat merangsang pikiran, perasaan, perhatian, dan kemauan siswa sehingga dapat mendorong terjadinya proses pembelajaran.

Melalui media, isi pelajaran akan lebih jelas maknanya karena penyampaian tidak semata-mata komunikasi verbal melalui penuturan kata-kata oleh guru. Oleh karena itu, dalam memilih media perlu memperhatikan beberapa pertimbangan yakni tujuan pembelajaran yang ingin dicapai, ketepatgunaan, kondisi siswa, dan biaya. Media sebagai bagian yang tak terpisahkan dari proses belajar mengajar demi terwujudnya tujuan pendidikan pada umumnya dan tujuan pembelajaran di sekolah pada khususnya harus diperhatikan ketersediaan, kondisi, dan penggunaannya baik oleh pihak sekolah, dinas pendidikan, maupun pemerintah (Disnawati \& Haning, 2019). Untuk menciptakan suasana belajar yang aktif dan kreatif maka media perlu memberikan inovasi-inovasi dan kreasi yang berkembang didunia sekarang tidak terbatas itu barang bagus dan berkualitas serta harganya mahal tetapi juga barang-barang yang berasal dari barang bekas (Siarni et al., 2015). Untuk itu pemanfaatan barang bekas untuk sebagai media pembelajaran pembelajaran matematika sangat penting untuk diterapkan khusunya kepada siswa tingkat dasar.

Ada beberapa pertimbangan yang perlu dilakukan oleh guru untuk memilih media yaitu; 1) Pertimbangan siswa, 2) Pertimbangan tujuan pembelajaran, 3) Pertimbangan strategi pembelajaran, 4) Pertimbangan kemampuan dalam merancang dan menggunakan media, 5) 
Pertimbangan biaya, 6) Pertimbangan sarana dan prasarana, dan 7) Pertimbangan efesiensi dan efektifitas.

Tujuan diadakannya kegiatan pengabdian kepada masyarakat ini adalah 1) Kegiatan pengabdian masyarakat merupakan wujud tanggung jawab dosen dalam mengimplementasikan Tridharma Perguruan Tinggi. 2) Meningkatkan pengetahuan siswa-siswa kelas 2 di SDN Unggulan 4 Made mengenai penggunaan barang bekas (kalender) sebagai media pembelajaran. 3) Meningkatkan kemampuan siswa-siswa kelas 2 di SDN Unggulan 4 Made mengenai penggunaan kalender bekas sebagai media berhitung. 3) Meningkatkan kemandirian siswasiswa kelas 2 di SDN Unggulan 4 Made dalam belajar dan memanfaatan barang bekas (kalender) sebagai media behitung. 4) Kegiatan ini merupakan transfer ilmu pengetahuan kepada guru matematika agar dapat membuat media pembelajaran di dalam kegiatan-kegiatan yang melibatkan peserta didik. Manfaat kegiatan 1) Sebagai sarana untuk menambahan wawasan dan pengetahuan tentang pemanfaatan barang kalender bekas sebagai media berhitung. 2) Sebagai wadah untuk pembelajaran yang lebih inovatif dan menyenangkan dan mudah untuk digunakan dalam berhitung. 3) Menambah wawasan dan pengetahuan tentang pemanfaatan barang bekas seperti kalender sebagai media pembelajaran khusunya sebagai media berhitung dalam matematika

\section{METODE PELAKSANAAN}

Sasaran pendampingan adalah guru matematika di SDN Unggulan 4 Made dengan melibatkan para siswanya. Alasan dipilihnya SDN Unggulan 4 Made tersebut, karena berdasarkan observasi pendampingan ini dibutuhkan untuk memberikan nilai tambah bagi SDN Unggulan 4 Made tersebut sehingga dapat meningkatkan standar kualitas kependidikan. Kegiatan dilaksanakan dalam waktu 1 hari. Tempat pelaksanaannya di SDN Unggulan Made, Kabupaten Lamongan.

Ada beberapa tahapan pelaksanaan yang dilakukan yaitu: 1) Penyusunan SAP (Satuan Acara Penyuluhan). 2) Berdiskusi dan negosiasi dengan Kepala Sekolah SDN Unggulan 4 Made. 3) Penyusunan dan penandatanganan kesepakatan antara Universitas Muhammadiyah Lamongan dengan Kepala Sekolah SDN Unggulan 4 Made untuk melaksanakan program penyuluhan tentang pemanfaatan kalender bekas sebagai media berhitung. 4) Penyuluhan tentang pemanfaatan kalender bekas sebagai media berhitung kepada siswa-siswi kelas 2 SDN Unggulan 4 Made dengan mempraktikkannya. 5) Evaluasi formatif terhadap peserta penyuluhan. 6) Terminasi dan penyusunan rencana tindak lanjut.

Sesuai dengan yang sudah dijelaskan di atas, pelaksanaan kegiatan ini dengan mengimplementasikan media pembelajaran. Didalam kegiatan ini ada beberapa bahan yang harus dipersiapkan yaitu kalender bekas, gunting dan alat tulis.

\section{HASIL DAN PEMBAHASAN}

Kegiatan dilaksanakan pada hari Senin, tanggal 9 bulan Maret 2020. Lokasi kegiatan adalah di SDN Unggulan 4 Made, Kabupaten Lamongan. Metode kegiatan adalah melalui kegiatan penyuluhan ini adalah ceramah, praktek langsung penggunaan kalender bekas sebagai media berhitung dan diskusi serta Tanya jawab dengan peserta.

Hasil pelaksanaan kegiatan pengabdian selanjutnya secara garis besar dapat dilihat dari penilaian beberapa komponen berikut ini, meliputi:

1. Keberhasilan target jumlah peserta pelatihan

Target jumlah peserta penyuluhan sebanyak 40 siswa, sedangkan dalam pelaksanaan kegiatan penyuluhan yang hadir sebanyak 30 siswa. Keberhasilan target jumlah peserta penyuluhan dapat dinilai sangat baik, karena $85 \%$ peserta yang diundang dapat ikut serta dalam penyuluhan. Gambar 1 menunjukkan peserta pelatihan. 


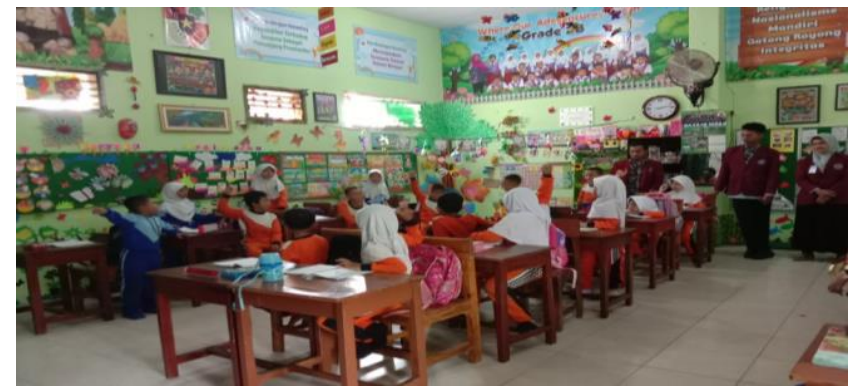

Gambar 1. Peserta Pelatihan

2. Ketercapaian tujuan penyuluhan

Tujuan penyuluhan adalah membekali siswa kelas 2 dengan pengetahuan tentang pemanfaatan kalender bekas sebagai media berhitung. Dalam pelaksanaan penyuluhan, beberapa materi disampaikan secara garis besar karena keterbatasan waktu, sehingga memungkinkan siswa kurang paham. Serta kondisi kelas yang terlalu ramai dan tidak terkontrol dengan baik. Pelaksanaan penyuluhan dilakukan setelah penyampaian materi untuk meningkatkan pengetahuan peserta. Jika dilihat dari ketercapaian tujuan penyuluhan dapat dinilai baik $(80 \%)$, dalam hal ini ada peningkatan pengetahuan peserta tentang pemanfaatan kelender bekas sebagai media berhitung. Gambar 2 menunjukkan pembelajaran pada peserta.

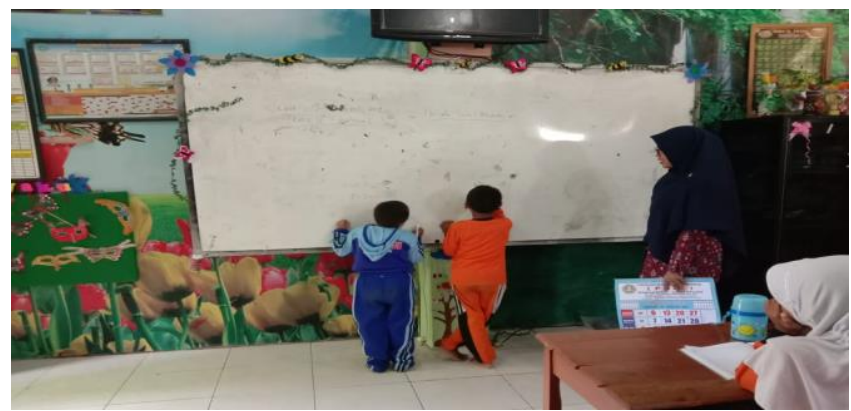

Gambar 2. Pembelajaran pada Peserta

3. Ketercapaian target materi yang telah direncanakan

Materi yang telah direncanakan, antara lain: pengertian media pembelajaran, pemanfaatan dan penggunaan barang bekas sebagai media berhitung. Semua materi penyuluhan telah disampaikan kepada peserta, namun karena keterbatasan waktu maka semua materi disampaikan secara detil, sehingga ketercapaian target materi yang telah direncanakan dapat dinilai baik (85\%). Gambar 3. Menunjukkan penjelasan materi pelatihan.

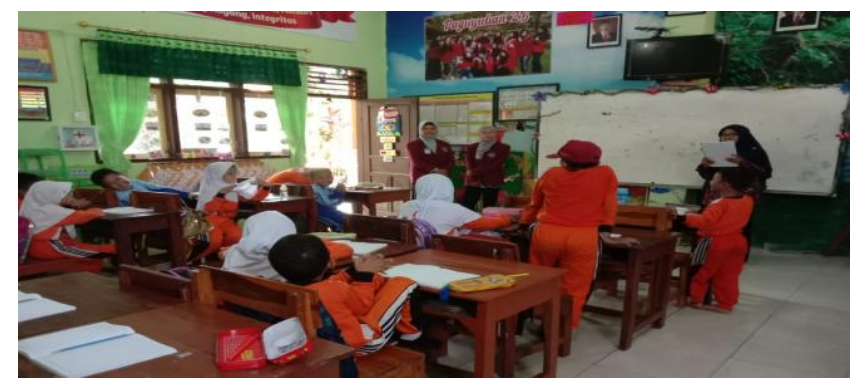

Gambar 3. Penjelasan Materi Pelatihan

4. Kemampuan peserta dalam penguasaan materi

Waktu pelaksanaan penyuluhan relatif singkat, asumsinya dengan waktu penyuluhan yang singkat maka akan menyebabkan peserta kurang memahami materi yang telah disampaikan oleh narasumber. Hal ini didukung dengan kondisi kelas yang terlalu ramai dan tidak terkontrol dengan baik sehingga memungkinkan kurang mampu menyerap materi dalam

Pemanfaatan Barang Bekas Sebagai Media Pembalajaran RAPATJURANG (Cara Cepat Penjumlahan dan Pengurangan) (Humairah, Rizka Rismawanda, Zahrotul Khamidah A, 
waktu singkat. Jika dilihat kemampuan siswa dalam penguasaan materi dapat dinilai cukup (75\%). Gambar 4. menunjukkan penguasaan materi peserta.

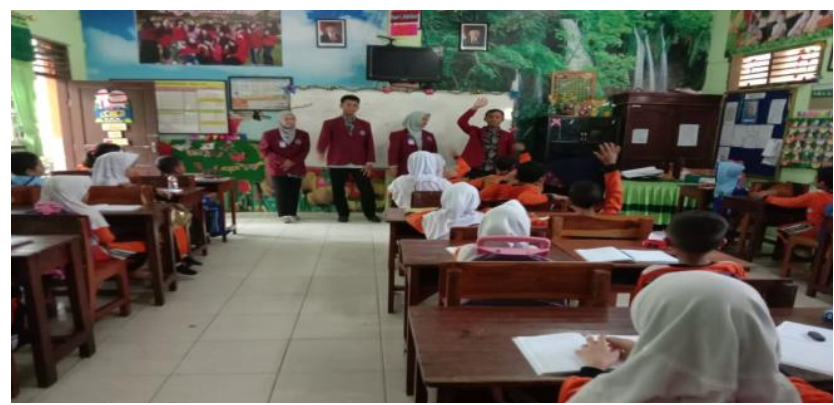

Gambar 4. Penguasaan Materi Peserta

Berdasarkan penilaian keempat komponen di atas, maka pelaksanaan kegiatan pengabdian berjudul "Pemanfaatan Barang Bekas Sebagai Media Pembalajaran RAPATJURANG (Cara Cepat Penjumlahan dan Pengurangan)" dapat dikatakan berhasil dan dinilai baik. Keberhasilan pelaksanaan kegiatan pengabdian selain diukur dari keempat komponen di atas, juga dapat dilihat dari kepuasan peserta setelah mengikuti kegiatan penyuluhan.

Pihak sekolah sangat puas dengan kegiatan yang diberikan tim karena memberikan manfaat cukup besar, antara lain: meningkatkan pengetahuan siswa-siswi tentang pemanfaatan barang bekas sebagai media pembelajaran di sekitarnya, memberikan alternatif pembelajaran berhitung berbasis siswa sekolah dasar, dan meningkatkan kesadaran siswa dalam mendukung upaya mengurangi sampah di lingkungan sekitarnya.

\section{KESIMPULAN}

Berdasarkan uraian dalam pembahasan, maka dapat diperoleh beberapa kesimpulan, antara lain:

1. Kegiatan pengabdian dapat meningkatkan pengetahuan masyarakat di lokasi pengabdian terhadap pemanfaatan barang bekas (kalender) sebagai media pembelajaran khususnya dalam berhitung.

2. Peningkatan pengetahuan peserta dilakukan dengan penyampaian materi pengertian media pembelajaran, pemanfaatan dan penggunaan barang bekas sebagai media berhitung berbasis siswa sekolah dasar dan simulasinya.

3. Untuk lebih meningkatkan pemahaman peserta dilakukan simulasi penggunaan kalender bekas sebagai media berhitung, dengan meberikan beberapa contoh soal untuk diselesaikan bersama.

\section{DAFTAR PUSTAKA}

Disnawati, H., \& Haning, F. O. (2019). Workshop Penggunaan Media Pembelajaran Berbasis Sampah dan Barang Bekas Bagi Guru MIN TTU. Bakti Cendana, 2(2), 38-44. https://doi.org/10.32938/bc.v2i2.280

Duda, H. J., Awang, I. S., \& Andri, A. (2018). PKM Pelatihan Pemanfaatan Bahan Bekas Sebagai Media Pembelajaran IPA bagi Kelompok Guru IPA. Jurnal Pengabdian Kepada Masyarakat, 8(1), 15-22. https://doi.org/10.30999/jpkm.v8i1.195

Humairah, H. (2018). Mengidentifikasi Penggunaan Alat Peraga Sebagai Media Pembelajaran Siswa Di SMP Islam Hasanuddin Dau-Malang. Prosiding Seminar Nasional Pendidikan Matematika, 1, 141-148.

Nisa, F. K., Masnipal, \& Tsaury, A. M. (2019). Pemanfaatan Bahan Bekas dan Bahan Alam Sebagai Media dalam Meningkatkan Kualitas Pembelajaran Anak Usia Dini. Prosiding Pendidikan Guru PAUD, 5(2). 
Siarni, S., Pasaribu, M., \& Rede, A. (2015). Pemanfaatan Barang Bekas Sebagai Media Pembelajaran untuk Meningkatkan Hasil Belajar IPA Siswa Kelas IV SDN 07 Salule Mamuju Utara. Jurnal Kreatif Tadulako, 3(2), 94-104.

http://jurnal.untad.ac.id/jurnal/index.php/JKTO/article/view/2871 